\title{
MARIA DO ROSÁRIO VS. JAIR BOLSONARO: UMA LEITURA (ANTI) DEMOCRÁTICA DO INQUÉRITO PENAL N. 3.932 $^{1}$
}

\author{
MARIA DO ROSÁRIO VS. JAIR BOLSONARO: AN (ANTI)DEMOCRATIC READING OF THE \\ CRIMINAL INVESTIGATION N. 3932
}

\author{
Marco Aurélio Rodrigues da Cunha e Cruz \\ Robison Tramontina ${ }^{3}$ \\ Grazieli Ana Paula Schmitz ${ }^{4}$
}

\begin{abstract}
Resumo: No presente trabalho teve-se por objetivo analisar, em forma de estudo de caso, algumas projeções (anti)democráticas da frase desferida pelo deputado federal Jair Bolsonaro em direção à igualmente deputada federal Maria do Rosário: "Não merece porque ela é muito ruim, porque ela é muito feia, não faz meu gênero, jamais a estupraria. Eu não sou estuprador, mas, se fosse, não iria estuprar, porque não merece." Essa frase deu ensejo a uma ação de natureza civil e ao Inquérito Penal n. 3.932, em trâmite no Supremo Tribunal Federal, objeto deste escrito. Neste texto, o estudo do Inquérito Penal n. 3.932 é lido com as lentes das obras Desonra, de J. M. Coetzee, e Sobre a Democracia, de Robert Dahl. Esse diálogo visa não somente fazer uma ligação entre as obras, mas demonstrar como a honra masculina é ponto forte e presente na questão da diferenciação do homem em relação à mulher. Empregando o método lógico-dedutivo, foi realizada uma pesquisa teórica, de cunho descritivo, com o levantamento bibliográfico e documental, buscando a análise e interpretação do referencial teórico e do caso em apreço.
\end{abstract}

Palavras-chave: Estupro. Desonra. Democracia.
Abstract: This paper aimed to analyze, in the form of a case study, some (anti)democratic projections of the phrase given by the Federal Deputy Jair Bolsonaro towards the Federal Deputy Maria do Rosário: "She doesn't deserve because she is very bad, because she is very ugly, she is not my type, I would never rape her. I'm not a rapist, but if I were, I wouldn't rape her because she doesn't deserve it." This sentence gave rise to an action for compensation for moral damages and to the Criminal Investigation No. 3.932, in process in the Federal Supreme Court, subject of this brief. In this text, the study of Criminal Investigation No. 3932 is read with the lenses of the works of Disgrace, by J. M. Coetzee, and On the Democracy, by Robert Dahl. This dialogue aims not only to make a connection between the works, but also to demonstrate how male honor is a strong and present point in the matter of the differentiation of men in relatuion to women. Using the logical-deductive method, a theoretical research was carried out, with a descriptive character and bibliographical research, seeking the analysis and interpretation of the theoretical reference and the present case.

Keywords: Rape. Dishonor. Democracy.

\footnotetext{
1 Este escrito faz uma singela homenagem à Doutora Eva Martínez Sampere, Professora Titular de Direito Constitucional da Universidad de Sevilla, Espanha (in memoriam).

2 Doutor e Mestre em Direito Constitucional pela Universidad de Sevilla; Professor Titular no Mestrado em Direitos Fundamentais da Universidade do Oeste de Santa Catarina; Avenida Nereu Ramos, 3777D, Seminário, 89813-000, Chapecó, Santa Catarina,Brasil; mar.cunhaecruz@gmail.com; https://orcid.org/0000-0002-9343-5358

3 Doutor e Mestre em Filosofia pela Pontifícia Universidade Católica do Rio Grande do Sul; Professor no Programa de Mestrado em Direitos Fundamentais da Universidade do Oeste de Santa Catarina; robison.tramontina@unoesc.edu.br; http:// orcid.org/0000-0002-1852-4983

4 Mestre em Direito pela Universidade do Oeste de Santa Catarina; Pós-Graduada em Direito Público Constitucional e Administrativo pela Universidade do Vale do Itajaí; grazielischmitz@outlook.com; https://orcid.org/0000-0001-7947-2139
} 


\section{Introdução}

É inevitável associar a palavra "personalidade" (do latim personalitas) à origem etimológica da palavra "pessoa" (persona em espanhol), a qual significa o conjunto de elementos inerentes ao ser humano. ${ }^{5}$ Persona provém de per (por, através) e sono (som), e expressava, em seus inícios, a máscara usada pelos atores nas representações teatrais na Grécia antiga e posteriormente em Roma. ${ }^{6}$ Prosopón, em grego, e personare ou resonare, em latim, eram os termos para a máscara com a boca aberta provida de lâminas metálicas, as quais faziam ressoar as vozes nas representações teatrais. $\bigcirc$ ressoador (ou a lingueta metálica) era o indicador dos tipos ou caracteres das máscaras, os quais tinham um papel personificado e conformavam a ideia de "personagem". Por isso se começou a chamar "persona" o personagem dessa figura diferenciada pela máscara, e dramatis personae a expressão de denominação para os atores. Fora do teatro, a voz comum atribuiu a "persona" a função ou qualidade que cada indivíduo representava no mundo, e posteriormente seu sentido teve equivalência ao própio ser humano.7

O papel personificado pelas partes do Inquérito Penal n. 3.932 guarda uma conexão imediata com a palavra "representação". Maria do Rosáiro Nunes (RS) e Jair Messias Bolsonaro (RJ) são "representantes do povo, eleitos, pelo sistema proporcional." (art. 45, Constituição Federal-1988). Indiscutivelmente podem ser classificados na categoria de personagem pública, pois ostentam um cargo ou função pública/política. ${ }^{8}$ Nesse sentido, é mais do que certo que as personagens públicas devem suportar, em sua condição de tais, que suas palavras e fatos se vejam submetidos ao escrutínio da opinião pública e, por conseguinte, a que não só se divulgue a informação sobre o que digam ou façam no exercício de suas funções, senão, inclusive, sobre o que digam ou façam à margem destas, sempre que tenham uma direta e evidente relação com o desempenho de seus cargos. Não sem razão já afirmou Kholer (1972, p. 29) que aquele que assume uma função eminentemente política dentro do Estado há de estar convencido de que os demais "têm o interesse de ver, em imagem, aquelas personalidades que de algum modo se destacam e se tornam objeto das conversas [...] possa fazer (o povo) uma ideia nítida das pessoas que governam o Estado, que influem na História, que edificam a ciência e a técnica [...]"

Nesse sentido, no presente trabalho tem-se por escopo analisar, em forma de estudo de caso, algumas projeções (anti)democráticas da frase desferida pelo deputado federal Jair Bolsonaro

\footnotetext{
5 Da língua etrusca (pershu), segundo Cifuentes (1995, p. 140).

6 Menezes (2004, p. 15) alude que a "persona" havia sido introduzida em Roma, proveniente da Grécia, pelo ator Roscius, 100 a. C.

7 Cifuentes (1995, p. 141 et seq) afirma que "persona" é ato e potência, pois compreende a idea de sujeito e de aptidão para sê-lo. Toda persona natural ou ideal tem a possibilidade de ser sujeito, pois este último vocábulo jurídico se utiliza com um significado especial no direito; é a persona que, por formar parte de uma relação jurídica, goza de um determinado direito ou tem que cumprir alguma obrigação. Sujeito representa o ato, e persona pode ser só a possibilidade de formar parte de um ato. A persona é, nesse sentido, o gênero e o sujeito, a espécie. Por isso, argumenta Cifuentes, a clássica divisão dos elementos gerais dos negócios jurídicos: sujeito, objeto, forma e causa.

8 Acrescem-se a essa classificação os personagens que possuem notoriedade pública, que conseguem essa característica por circunstâncias que assim os fazem (não necessariamente ligadas à profissão) e os particulares, os demais (CUNHA; CRUZ, 2009, p. 336).
} 
em direção à igualmente deputada federal Maria do Rosário. "Não merece porque ela é muito ruim, porque ela é muito feia, não faz meu gênero, jamais a estupraria. Eu não sou estuprador, mas, se fosse, não iria estuprar, porque não merece." Essa frase deu ensejo a uma ação de natureza civil ${ }^{9}$ e à acusação da prática de três crimes: incitação ao crime (art. 286, CP), injúria (art. 140) e calúnia (art. 138), formalizados no Inquérito Penal n. 3.932, em trâmite no Supremo Tribunal Federal, objeto deste escrito. A decisão de recebimento da denúncia por incitação ao crime (art. 286, CP) e de recebimento da queixa por injúria (art. 140) data de 21 de junho de 2016 (TRIBUNAL SUPERIOR DE JUSTIÇA, 2016). Os Embargos de Declaração a essa decisão foram desprovidos em 07 de março de 2017.

Neste texto, o estudo do Inquérito Penal n. 3.932 é lido com as lentes das obras Desonra, de J. M. Coetzee, e Sobre a Democracia, de Robert Dahl. O diálogo visa não somente fazer uma ligação entre as obras, mas demonstrar como a honra masculina é ponto forte e presente na questão da diferenciação do homem em relação à mulher. Para tratar do tema, optou-se por dividir este trabalho em três partes. Em primeiro momento será analisado exclusivamente o Inquérito Penal n. 3.932, com foco no voto do Ministro relator, Luiz Fux. Em segundo e terceiro momentos, far-se-á uma interconexão do Inquérito em apreço aliado às obras de Coetzee e Dahl, respectivamente.

Na primeira parte, relativa ao Inquérito Penal n. 3.932, o estudo se dedicará à análise de comentários machistas proferidos em eventos distintos pelo parlamentar Jair Messias Bolsonaro em face à também parlamentar Maria do Rosário, desdobrando-se os eventos e verificando as razões jurídicas relativas aos crimes atribuídos em consequência do discurso do denunciado.

Na segunda parte, será estudado o discurso atribuído às mulheres aliado à obra de Coetzee, cujo objetivo é, comparando um caso real de um parlamentar brasileiro ao de uma criação literária, apresentar suas semelhanças e fazer uma crítica à representação imposta às mulheres, ou seja, de seres inferiores e submissos às vontades masculinas. Tal fato pode ser visualizado nas narrativas tanto do Inquérito quanto da obra, quando, naquele, o denunciado acredita dispor do poder de escolha em violentar uma mulher, do seu merecimento de abuso sexual, enquanto que na obra, demonstram-se dois casos de abuso sexual os quais o protagonista vê com naturalidade.

Na terceira parte far-se-á uma conexão dessas narrativas (a real e a literária) com o livro de Robert Dahl. A democracia de Dahl conduz ao argumento de que a condição natural da humanidade é a desigualdade, e não a igualdade, muito embora todos desejem esta. No entanto, explica que a ideia de igualdade humana é aceita por explicitar uma pretensão futura, demonstrando que almejar igualdade é tencionar para o que deveria ser (considerar todos iguais).

A ligação do argumento de Dahl com o Inquérito Penal n. 3.932 se desenvolverá nesse sentido, ou seja, demonstrando que, a par de reconhecer que todos possuem sua desigualdade

\footnotetext{
9 A ação de indenização por danos morais, ajuizada em 2014, foi sentenciada como procedente para condenar ao pagamento de R \$ 10.000,00. Foi negado provimento à apelação interposta pelo Deputado e dado parcial provimento à apelação da Deputada, para que fosse determinada a publicação de retratação em jornal de grande circulação, na página oficial do recorrente no Facebook e na página pessoal dele no YouTube. A Terceira Turma do Superior Tribunal de Justiça, por unanimidade, negou provimento ao Recurso Especial n. 1.642.310, relatora Min. Nancy Andrighi (TRIBUNAL SUPERIOR DE JUSTIÇA, 2017).
} 
natural, é almejando a igualdade que se atinge a democracia - e, assim, a inclusão das mulheres. Além disso, serão apresentados os conceitos sobre poliarquia (democracia poliárquica), igualdade intrínseca e superioridade intrínseca a fim de demonstrar os parâmetros para uma real e concreta democracia entre homens e mulheres.

Cumpre observar que, considerando a amplitude do tema "democracia" presente na obra de Dahl, neste trabalho será abordado apenas o que for pertinente ao objetivo de análise (concepção feminista, integração da mulher). Por óbvio, é intuitivo que não se trata de um texto estritamente dogmático-jurídico. Contudo, empregou-se o método lógico-dedutivo e foi realizada uma pesquisa teórica, de cunho descritivo, com o levantamento bibliográfico e documental, buscando a análise e interpretação do referencial teórico e do caso em apreço.

\section{Sobre o Inquérito Penal n. 3.932}

Esta primeira seção faz uma análise do recebimento ou não de denúncia e queixa-crime provenientes do Inquérito Penal n. 3.932, em trâmite no Supremo Tribunal Federal, em virtude de referir-se à investigação em face do parlamentar Jair Messias Bolsonaro.

O caso teve origem numa manifestação do parlamentar no plenário da Câmara dos Deputados em 09 de dezembro de 2014 e na reportagem concedida em 10 de dezembro de 2014 para o jornal Zero Hora, na qual afirmou publicamente que não estupraria a Deputada Federal Maria do Rosário porque ela não merece. Quando indagado sobre o motivo, respondeu: "Não merece porque ela é muito ruim, porque ela é muito feia, não faz meu gênero, jamais a estupraria. Eu não sou estuprador, mas, se fosse, não iria estuprar, porque não merece."

Diante disso, o Ministério Público Federal ofereceu denúncia, imputando ao parlamentar a prática do crime de incitação ao crime, definido no art. 286 do Código Penal (CP). A ofendida, por sua vez, propôs queixa-crime (Pet 5243) no tocante aos crimes de calúnia (art. 138, CP) e injúria (art. 140, CP). Para tanto, entendeu-se pelo concurso formal de crimes, justificando o julgamento em conjunto, tanto da denúncia, quanto da queixa-crime.

\subsection{Os três argumentos acusatórios}

A acusação pelo crime de incitação ao crime de estupro provém do fato de o parlamentar ter dito que não estupraria a deputada "porque ela não merece" (Incitação ao crime. Art. 286 - Incitar, publicamente, a prática de crime: Pena - detenção, de três a seis meses, ou multa). A Procuradora-Geral da República enfatizou que "Embora o crime seja de menor potencial ofensivo, deixa de apresentar proposta de transação penal, tendo em vista o disposto no art. $76, \$ 2^{\circ}$, III, parte final, da Lei n. 9.099/95, por ser insuficiente a adoção da medida, considerando os motivos, as circunstâncias e a repercussão do crime." O relator, Ministro Luiz Fux, entendeu que o emprego do vocábulo "merece" 
faz com que o estupro seja um prêmio para aquelas que possuem beleza e que revela a "interpretação de que o homem estaria em posição de avaliar qual mulher 'poderia' ou 'mereceria' ser estuprada."

O Ministro pontuou que a expectativa normativa é de que a violência sexual seja reprovada. No entanto, com comentários desse nível, os quais desprezam o bem jurídico protegido (dignidade sexual), perpetua-se uma "cultura que ainda subjuga a mulher, com potencial de instigar variados grupos a lançarem sobre a própria vítima a culpa por ser alvo de criminosos sexuais." Ademais, as notícias de estupro coletivo reforçam a necessidade de preocupar-se com os discursos que "intensifiquem a vulnerabilidade das mulheres."

A decisão de recebimento da denúncia apontou que o crime de incitação é um crime contra a paz pública, formal (independe de resultado naturalístico), de perigo abstrato e menor potencial ofensivo (pena máxima seis meses). Caracteriza-se tanto pela influência em fazer surgir a ideia de crime antes inexistente, quanto pela instigação, reforçando eventual propósito existente, os quais são possíveis de serem vislumbrados no caso, pois após os comentários do deputado, a deputada foi vítima de ataques ofensivos à sua honra nas redes sociais. Ou seja, com os versos que proferiu, instigou internautas à prática de crimes contra a honra:

Mas aí essa puta naum defende bandido que que tem ele dá uma estupradinha nela?;

$[\ldots]$

Eu estupraria Maria do Rosário, mas com os dedos, porque com aquela cara nem com Viagra. (informações verbais).

Em vista disso, e levando em conta a classificação do tipo penal, o relator entende que as declarações do parlamentar possuem potencial para "reforçar eventual propósito existente em parte daqueles que ouviram ou leram as declarações, no sentido da prática de violência física e psíquica contra a mulher."

A deputada federal Maria do Rosário Nunes, na qualidade de vítima, ajuizou queixa-crime em face de Jair Messias Bolsonaro, imputando-lhe a prática dos crimes de calúnia (art. 138, CP) e injúria (art. 140, CP). Segundo a vítima, as ofensas relativas a ambos os crimes ocorreram em discurso no plenário da Câmara dos Deputados no dia 09 de dezembro de 2014 e, novamente, uma injúria em relação a uma entrevista concedida ao Jornal Zero Hora em 10 de dezembro de 2014. Os crimes de calúnia e injúria teriam se consumado em um discurso realizado no plenário da Câmara dos Deputados, quando o deputado se referia a fatos ocorridos 11 anos antes:

Há poucos dias você me chamou de estuprador no Salão Verde e eu falei que eu não estuprava você porque você não merece. Fique aqui para ouvir [...] Maria do Rosário, por que não falou sobre sequestro, tortura, execução do Prefeito Celso Daniel do PT? Nunca ninguém falou nada sobre isso aqui e estão tão preocupados com os direitos humanos... Vá catar coquinho! Mentirosa deslavada e covarde.

No tocante ao segundo crime de injúria, a deputada alega que se configurou no momento em que o querelado concedia entrevista ao Jornal Zero Hora quando afirmou: "Ela não merece porque 
ela é muito ruim, porque ela é muito feia. Não faz meu gênero. Jamais a estupraria." Além de que, em 09 de dezembro, o deputado postou em sua página oficial no canal Youtube um vídeo intitulado "Bolsonaro escova Maria do Rosário".

\subsection{Os contra-argumentos à acusação de cada crime}

A defesa sublinhou que os fatos se encontravam cobertos pela imunidade parlamentar material, descrita no art. 53 da Constituição Federal de 1988 (Art. 53. Os Deputados e Senadores são invioláveis, civil e penalmente, por quaisquer de suas opiniões, palavras e votos). No mérito, por não ter sofrido condenação penal, suscitava a aplicação de proposta de transação penal, mas não queria dela se beneficiar.

No tocante ao crime de incitação, a defesa alega contra a caracterização do crime, além de argumentos procedimentais, ${ }^{10}$ a impossibilidade de, pela fala do denunciado, encontrar "pretensões que denotem qualquer tipo de incentivo à prática de estupro, tampouco instigação ou encorajamento." Além do que, o protesto virtual que nasceu em virtude dos comentários do denunciado, que teve como emblema a frase EU NÃO MEREÇO SER ESTUPRADA ${ }^{11}$ escrita no corpo de uma mulher, "também estaria instigando que outras mulheres merecessem e incitando, assim, a prática de estupro." Consignou que na sindicância instaurada pela Corregedoria da Câmara dos Deputados resultou a decisão de inexistência da ilicitude, com o argumento de que se tratou de mera discussão com opiniões divergentes.

No tocante aos crimes de injúria e calúnia, também requereu a aplicabilidade da imunidade parlamentar material, prevista no texto constitucional. $\bigcirc$ querelado contra-argumentou que, em 2003, quando concedia entrevista no Salão Verde à RedeTV, a querelante "se aproximou e tumultuou sua fala" e que, portanto, as afirmações que fez foram em legítima defesa à ofensa que recebeu:

Em resumo, naquela oportunidade, é possível atestar o seguinte diálogo:

Maria do Rosário: O senhor é responsável por essas mortes todas... por estupro, por essa violência.

Jair Bolsonaro: Estupro?

Maria do Rosário: É. O senhor é que promove sim.

Jair Bolsonaro: Grava aí. Grava aí. Eu sou estuprador agora. Eu sou estuprador. Maria do Rosário: É. É sim.

Jair Bolsonaro: Olha. Jamais iria estuprar você porque você não merece.

Maria do Rosário: Eu lhe dou uma bofetada na cara.

Jair Bolsonaro: Dá que eu lhe dou outra.

Seguem-se ofensas.

\footnotetext{
10 "não teria sido narrada, na denúncia, a instigação de 'pessoas determinadas ou indeterminadas da coletividade a praticar crimes específicos."

11 Trata-se de protesto iniciado pela jornalista Nana Queiroz, por meio da internet, valendo-se, em seguida à divulgação das declarações do acusado, da postagem de uma foto em rede social em que aparece sem camiseta e com a frase EU NÃO MEREÇO SER ESTUPRADA, com intuito de combater o que se considerou uma ofensa grave contra as mulheres do País.
} 
A respeito dos fatos ocorridos no plenário da Câmara de Deputados em 09 de dezembro de 2014, o querelado "teria apenas respondido ao discurso da Querelante, que o antecedeu no púlpito", e que após sua saída, o deputado não trouxe novas declarações capazes de ser interpretadas ou caracterizadas como tipo penal atentatório à honra, "tendo, apenas feito alusão ao fato ocorrido em 2003." A fala, em dezembro de 2014, foi a seguinte:

Não saia, não, Maria do Rosário, fique aí, fique aí, Maria do Rosário. Há poucos dias você me chamou de estuprador no Salão Verde e eu falei que eu não estuprava você porque você não merece. Fique aí para ouvir, Maria do Rosário, por que não falou sobre sequestro, tortura, execução do Prefeito Celso Daniel, do PT? Nunca ninguém falou nada sobre isso aqui, e estão tão preocupados com os direitos humanos. Vá catar coquinho. Mentirosa, deslavada e covarde. Parabéns aos vagabundos do Brasil que estão sob o guarda-chuva da Comissão de Direitos Humanos.

Alega que a Mesa Diretora da Câmara dos Deputados concluiu pela inexistência de ilicitude, pois se tratou de "mera discussão com opiniões divergentes." No tocante ao segundo crime de injúria que teria se realizado em razão de uma entrevista concedida ao Jornal Zero Hora no dia seguinte ao fato ocorrido em 09 de dezembro de 2014 no púlpito da Câmara dos Deputados, a defesa do querelado considera que: "os termos 'ruim', 'muito feia' e 'não faz meu gênero' não podem ser considerados ofensivos, ou será que temos que achar que todos são bons, bonitos e que fazem nosso gênero?"

Quanto às manifestações dos internautas nas redes sociais, seria consequência de fato que envolve pessoas públicas e que, "em virtude de manifestações agressivas ao querelado, inclusive por parte da querelante, este também é vítima de ofensas graves e ameaçadoras em diversas redes sociais." Ademais, entende que, na configuração típica dos fatos faltam o animus caluniandi ou animus diffamandi, pois "expressões eventualmente insultuosas, proferidas em clima de debate e no exercício do direito de crítica ou censura profissional, ainda que veementes" não podem ser consideradas como determinantes à configuração de crimes contra a honra.

Por fim, para caracterizar o crime de calúnia, "o agente tem de fazer, ao menos, referência ao lugar ou ao tempo, a fim de que a imputação não se configure como mero insulto, e sim como calúnia."

\subsection{Das razões jurídicas da decisão de recebimento da denúncia}

Segundo o relator Ministro Luiz Fux, o concurso formal justificou o julgamento conjunto da denúncia e da queixa. Comentou ser impositivo o oferecimento da denúncia pela não formalização da proposta de transação penal pelo titular da ação penal pública e pelo desinteresse do acusado quanto ao benefício.

O relator sustentou, ainda, que a jurisprudência do Supremo Tribunal Federal assenta que a garantia constitucional da imunidade material ampara o parlamentar "qualquer que seja o âmbito 
espacial em que exerça a liberdade de opinião, sempre que suas manifestações guardem conexão com o desempenho da função legislativa ou tenham sido proferidas em razão dela (prática in officio e propter officium, respectivamente)." (grifo do autor). Nesse tom, observou que:

as afirmações feitas pelo parlamentar possam ser relacionadas ao exercício do mandato, elas devem revelar teor minimamente político, referido a fatos que estejam sob debate público, sob investigação do Congresso Nacional (CPI) ou dos órgãos de persecução penal ou, ainda, sobre qualquer tema que seja de interesse de setores da sociedade, do eleitorado, organizações ou quaisquer grupos representados no parlamento ou com pretensão à representação democrática.

Tais hipóteses não foram vislumbradas nas declarações que originaram as ações penais, pois não guardavam qualquer relação com o exercício do mandato e foram proferidas em entrevista a órgão de imprensa, não reclamando, desse modo, a imunidade. A conclusão do relator sobre a exclusão da imunidade é feita com a seguinte assertiva: "cuidando-se de declarações firmadas em entrevista concedida a veículo de grande circulação, cujo conteúdo não se relaciona à garantia do exercício da função parlamentar, não incide a imunidade prevista no art. 53 da Constituição Federal."

Em relação ao crime do art. 286, incitação ao crime, pode-se denotar, segundo o Ministro Luiz Fux, que a manifestação do acusado, parlamentar, pessoa pública detentora de múnus público, tem o potencial de incitar que os homens exponham as mulheres à fragilidade e à violência, seja ela física, sexual ou psicológica, inclusive à prática de novos crimes atentatórios à honra, tanto da vítima quanto de outras mulheres. O relator considera que, tendo se utilizado do termo "merece", a expressão dá a entender que os homens têm o condão de avaliar que mulheres merecem ser estupradas. Além do que, o termo "não apenas menospreza a dignidade da mulher, como atribui às vítimas o merecimento dos sofrimentos que lhe sejam infligidos." (grifo do autor). Afirmou que "no caso de incitação do crime de estupro, que a conduta estará preenchida quando o valor do bem jurídico protegido pelo crime de estupro for diminuído, o que, consequentemente, incitaria a sua prática."

De fato. Acreditar que essas atitudes machistas, por mais que pareçam pequenas, são normais, que não inspiram outros homens e que não trazem consequências para as mulheres é, como entende Pateman (1993), apresentar o direito patriarcal como reflexo da própria natureza, ou seja, como poder dos homens sobre as mulheres advindo da natureza.

É por isso que o relator considera que "não se podem subestimar os efeitos dos discursos que reproduzem o rebaixamento da dignidade sexual da mulher", pois eles têm o poder de gerar consequências sobre como as pessoas consideram essa prática, levando até mesmo ao encorajamento para fazêla. (grifo do autor). Portanto, como o crime de incitação é um crime de proteção mediata, de bens jurídicos secundários, não se pode ignorar que, desprezando o bem jurídico protegido (dignidade sexual), pois o comentário do parlamentar

reforça e incentiva a perpetuação dos traços de uma cultura que ainda subjuga a mulher, com potencial de instigar variados grupos a lançarem sobre a própria vítima a culpa 
por ser alvo de criminosos sexuais, deixando, a depender da situação, de reprovar a violação sexual, como seria exigivel a mercê da expectativa normativa. (grifo do autor).

E isso se pôde visualizar nas manifestações de leitores nas redes sociais, lançando mão de novos crimes contra a honra da deputada.

Observou que a interpretação das normas jurídicas deve conferir máxima eficácia aos direitos humanos e fundamentais, à luz do direito interno e das convenções e tratados internacionais internalizados. Citou os tratados de proteção à vida, à integridade física e à dignidade da mulher, com destaque para a Convenção Interamericana para Prevenir, Punir e Erradicar a Violência contra a Mulher - "Convenção de Belém do Pará" (1994); a Convenção sobre a Eliminação de Todas as Formas de Discriminação contra a Mulher - "Carta Internacional dos Direitos da Mulher" (1979); além da Lei Maria da Penha, Lei n. 11.340/2006.

Ademais, em repúdio às declarações do deputado, com o uso da palavra "mereço", manifestantes deram início a uma campanha nas redes sociais (\#eunãomereçoserestuprada) a fim de demonstrar a gravidade contra as mulheres do tom ofensivo empregado, sobretudo porque mantêlas "em permanente estado de intimidação" abala o desenvolvimento da personalidade e de suas potencialidades.

O cuidado com a forma de expressar, sobretudo de pessoas públicas, com o agravante de serem representantes eleitos pelo povo que, se não empregado o devido cuidado, têm o condão de disseminar discursos de ódio, de poder e de intimidação, deve ser primordial, principalmente em momentos em que se vivenciam casos de estupros coletivos.

Dessa forma, o relator entendeu pelo recebimento da denúncia quanto ao tipo penal incitação ao crime (art. 286, CP), porquanto restar configurada a característica "potencial de reforçar eventual propósito existente ofensivo contra as mulheres" (refletido nas manifestações de crimes contra a honra pela internet), pois "conclusão contrária poderia conduzir à compreensão de que a reprodução do discurso narrado na inicial é tolerável, [...] ampliando sua situação de vulnerabilidade."

A imputação do crime de injúria ocorreu pelas mesmas declarações proferidas pelo querelado, as quais teriam ofendido a honra subjetiva da vítima. A defesa, por sua vez, sustentou a ausência de animus injuriandi e que as declarações foram meras respostas às ofensas proferidas pela querelante. Inobstante, para o relator, ao fazer uso da expressão "ela não merece", manifesta-se presente o efetivo potencial de rebaixamento da dignidade moral ao ofender sua condição de mulher, expô-la à humilhação pública, "além de associar as características da mulher à possibilidade de ser vítima de estupro." O Ministro Luiz Fux também considerou estar presente o animus offendendi, porquanto não vislumbra outro animus capaz de afastar a incidência da ofensa e não considera ser retorsão imediata, pois as primeiras ofensas ocorreram cerca de 11 anos antes (em 2003) e quanto às ofensas da entrevista ao Jornal Zero Hora, em 2014, a defesa não fez menção de acometimentos praticados pela vítima ao parlamentar, fato que, portanto, não restou comprovado. Diante disso, recebeu a queixa-crime quanto à injúria (art. 140). 
A queixa-crime atribuiu, também, ao querelado o crime de calúnia por ter afirmado falsamente que a querelante o chamou de "estuprador". No entanto, como o crime prevê a atribuição falsa de fato definido como crime e a inicial não narrou como a afirmação de o deputado ter sido chamado de "estuprador" pela querelante poderia ofendê-la em sua honra, o relator rejeitou a queixa pelo crime de calúnia.

O Ministro Luiz Fux foi seguido, integralmente, pelo Ministro Edson Fachin, pela Ministra Rosa Weber e pelo Ministro Luís Roberto Barroso. O Ministro Marco Aurélio argumentou que os fatos ocorreram no Plenário da Câmara dos Deputados, com repercussão posterior na imprensa. Por esse motivo, não recebeu a queixa-crime, por entender aplicável a imunidade parlamentar. De igual maneira, não recebeu a denúncia, com as seguintes razões:

Assentaremos, para efeito de cumprir esse estágio embrionário da ação penal, que, ante as peculiaridades do caso e a origem da utilização do vocábulo "estuprar", buscou o Deputado Federal incitar os homens à prática delituosa? Onde está o elemento subjetivo do tipo, o dolo? Reconheço tratar-se de crime formal, mas não posso considerar as brincadeiras feitas em redes sociais aqui citadas, nem os comentários desairosos lançados pelos cidadãos que perderam tempo com isso. Houve um arroubo de retórica, a utilização de metáfora, quando o denunciado - e não o estou colocando em divã para, realmente, como profissional da área, saber a intenção - disse que não a estupraria por ela ser feia - já afirmei não concordar, tenho-a como uma moça bonita. Quis dizer que não manteria relações com ela, mesmo se, apartada a questão ideológica, ela assim o desejasse. O Supremo, ao receber a denúncia e dar continuidade à queixa-crime, não estará contribuindo para o tratamento igualitário, presentes os gêneros masculino e feminino. A meu ver, acirrará os ânimos e adentrará - como falei com desassombro - o campo do preconceito invertido. Peço vênia à maioria já formada para, aqui, sim - e não o fiz no episódio apontado pela ilustre advogada da tribuna, no que o senador Romário assacou vocábulos contra dirigente da Confederação Brasileira de Futebol, e votei pelo recebimento da queixa-crime -, dizer que não tenho como desprezar, sob pena de esvaziar totalmente o instituto, a imunidade parlamentar. Ambos atuaram na defesa dos respectivos perfis.

Concluindo, pedindo excusas por ter me alongado um pouco sobre a matéria - não recaindo sobre mim qualquer suspeita de machismo, já que, há pouco, recebi prêmio, antes apenas outorgado a mulheres, e foi necessária a alteração do regimento para ocorrer a outorga, Bertha Lutz -, não dou sequência à queixacrime e não recebo a denúncia.

É como voto.

Com a superação do objetivo inicial descritivo do caso investigado no Inquérito Penal 3.932, cabe, a partir de agora, relacionar os fatos dessa narrativa real com o da narrativa ficcional externada em Desonra, de autoria do prêmio Nobel de Literatura de 2003: J. M. Coetzee.

\section{Reflexões sobre Desonra de J. M. Coetzee}

O elo entre o procedimento penal e a obra literária tem por objetivo apresentar como o discurso machista presente na ficção não se restringe a ela, mas está presente na realidade social sendo, dessa forma, compreendido como aquele que deixa transparecer o pensamento da grande 
maioria dos membros da sociedade. Em Desonra, Coetzee apresenta, além de falas, casos de violência sexual, e faz uma crítica em como a sociedade reage e como essa reação atinge a vítima (inclusive diante de sua atitude - ou não - de denunciar o crime).

Desonra narra a história de David Lurie, um personagem de meia-idade (52 anos), divorciado e professor da matéria de Comunicações na Universidade Técnica do Cabo. No livro, o autor apresenta três formas de relação: inicialmente o sexo pago (mulher-objeto); secundariamente o sexo sob poder de tutela (menina-aluna; beleza deve ser compartilhada; abuso sexual); e, finalmente, o sexo sob violência (jovem; homem-bicho; estupro).

A obra inicia com o relato de um envolvimento semanal que D. Lurie possui com uma prostituta de origem muçulmana, de nome Soraya. Nesse ponto já é possível visualizar comentários de tom machista, no momento em que não compreende como Soraya pode ter uma opinião e julgar, a partir da profissão que exerce, sobre as mulheres que fazem top less. Pensa ele que, a depender do que a mulher escolhe para desempenhar em sua vida, perde seus direitos de opinião.

Soraya é alta e magra, de cabelo preto comprido e olhos escuros, brilhantes. Tecnicamente, ele tem idade para ser seu pai; só que, tecnicamente, dá para ser pai aos doze. [...] Suas opiniões são surpreendentemente moralistas. Fica ofendida com as turistas que despem os seios ("tetas", ela diz) nas praias públicas; acha que os vagabundos deviam ser recolhidos e postos para trabalhar, varrendo as ruas. Ele não pergunta como ela consegue coadunar essas opiniões com o tipo de trabalho que faz. (COETZEE, 2011, p. 8, grifo nosso).

Um professor que, apesar de "mulherengo", tece a todo o momento comentários machistas e depreciativos em relação às mulheres. Além disso, sua preferência de envolvimento são sempre moças muito mais jovens. A obra demonstra um certo tom de "homem perseguidor", o qual está sempre pesquisando, invadindo a vida das mulheres com quem se relaciona. Essa característica é perceptível quando D. Lurie contrata detetives para descobrir o nome verdadeiro, endereço e telefone de Soraya, além de tentar contato, o que a faz ficar irritada e responder que não sabe de quem ele se trata, além de exigir que nunca mais a assedie em sua própria casa. Essa atitude se repete quando se envolve com Melanie, sua aluna na Universidade do Cabo:

Ele devia parar por aí. Mas não para. No domingo de manhã vai dirigindo até o campus vazio e entra no escritório do departamento. Do armário de arquivos tira a ficha de Melanie Issacs e copia seus dados pessoais: endereço da família, endereço na Cidade do Cabo, número de telefone. Disca o número. Uma voz de mulher atende. Melanie? (COETZEE, 2011, p. 25, grifo nosso).

Melanie Issacs é uma aluna de D. Lurie do curso de românticos. Jovem, 30 anos mais nova que ele, além de ser sua aluna, isto é, estar sob sua tutela. Apesar disso, leva-a para sua casa e tenta com que passe a noite com ele.

Mas a menina que trouxe para casa não é só trinta anos mais nova que ele: é aluna, sua aluna, está sob sua tutela. [...] Juntos, compõe o quadro: a jovem esposa de roupas ousadas e bijuterias espalhafatosas entrando pela porta da rua, sentindo o cheiro 
no ar; o marido, o certinho apagado, de avental, mexendo uma panela na cozinha cheia de fumaça. Inversões: matéria-prima da comédia burguesa. (COETZEE, 2011, p. 20, grifo nosso).

O personagem acha lindo o quadro a que pertence: para ele, a mulher não precisa cozinhar, não precisa ter qualidades, ter desenvolvimento intelectual. Basta que seja bonita. Que se vista de forma atraente. Ser um troféu para o homem sem graça carregar. Contempla e acha graça no papel de casal "homens ricos, mulheres gostosas". Acredita que a beleza da mulher é seu dote e deve ser compartilhada.

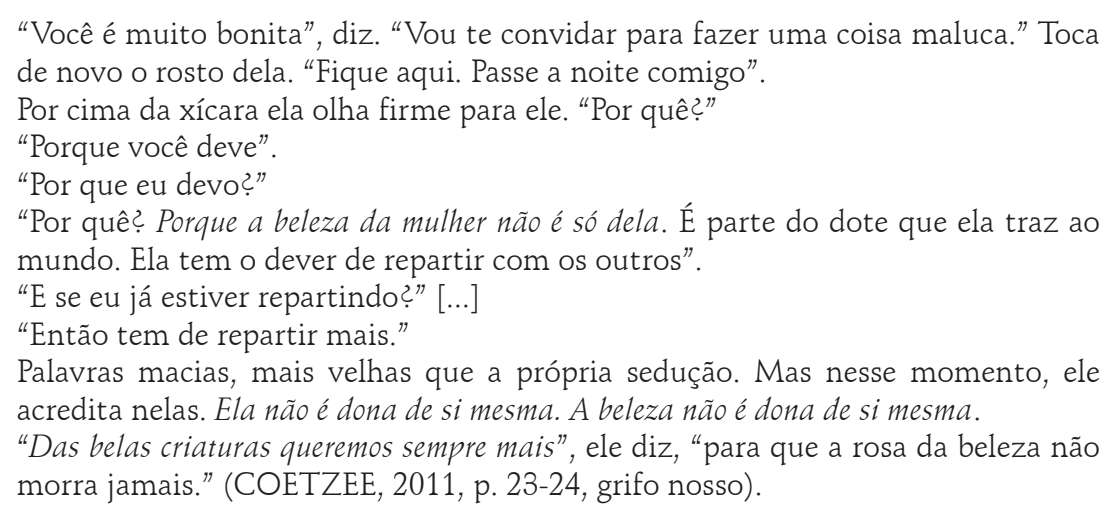

Mesmo que em primeiro momento a jovem rejeite, nos encontros que se seguem o "envolvimento" acontece, e a trama narra as situações de assédio de D. Lurie com Melanie:

Ele a leva de volta para casa. No chão da sala, ao som da chuva tamborilando nas janelas, faz amor com ela. Seu corpo é claro, simples, perfeito à sua maneira; embora fique passiva do começo ao fim, ele acha o ato agradável, tão agradável que do climax cai direto para o abandono total.

Quando volta a si a chuva parou. A menina está deitada embaixo dele, olhos fechados, as mãos caídas acima da cabeça, uma ligeira ruga na testa. As mãos dele estão debaixo do suéter de lã áspera, nos seios dela. As meias e a calcinha dela enroladas no chão; as calças nos tornozelos. [...] Ela vira o rosto, liberta-se, recolhe suas coisas, sai da sala. (COETZEE, 2011, p. 27, grifo nosso).

Mesmo Melanie externando sua falta de interesse, o professor não demonstra a menor importância sobre a opinião e os sentimentos da aluna. Ainda que diante da passividade da jovem, o ato o agrada. Em seguida, a partir da pesquisa dos seus dados pelos arquivos da universidade, passa a visitá-la sem aviso prévio e, mesmo diante de negativas por parte da jovem em relação às suas investidas, o professor força relação sexual, mas o curioso é que, para ele, apesar de reconhecer ser indesejado da parte dela, acredita piamente não caracterizar estupro:

Ele não avisou que vinha; ela fica surpresa demais para resistir ao intruso que impõe sua presença. Quando ele a pega nos braços, ela fica mole como uma marionete. Palavras duras como bastões batem o delicado labirinto de seu ouvido. "Não, agora não!", ela diz, se debatendo. "Minha prima vai voltar logo!"

Mas nada o detém. Ele a leva para o quarto, arranca aqueles chinelos absurdos, beijalhe os pés, perplexo com o sentimento que ela evoca. [...] 
Ela não resiste. Tudo o que faz é desviar: desvia os lábios, desvia os olhos. Deixa que ele a leve para a cama e tire sua roupa: até o ajuda, levantando os braços e depois os quadris. Pequenos arrepios de frio a percorrem; assim que está nua, enfia-se debaixo do cobertor xadrez como uma toupeira que se enterra, e vira as costas para ele.

Estupro não, não exatamente, mas indesejado mesmo assim, profundamente indesejado. Como se ela tivesse resolvido ficar mole, morrer por dentro enquanto aquilo durava, como um coelho quando a boca da raposa se fecha em seu pescoço. De forma que tudo o que lhe fosse feito, fosse feito, por assim dizer, de longe. [...]

Um erro, um grande erro. Nesse momento, ele não tem a menor dúvida, ela, Melanie, está tentando se limpar, se limpar dele. (COETZEE, 2011, p. 33, grifo nosso).

Dos acontecimentos resulta uma queixa de estupro feita pela aluna junto à Secretaria de Assuntos Estudantis, que dá ensejo à realização de uma audiência perante a instituição de ensino superior na qual D. Lurie trabalha. O caso se torna público, e o professor passa por uma audiência com um corpo colegiado julgador formado por seus colegas de profissão que pretendem solucionar a transgressão de maneira que passem pela situação de forma a não manchar a credibilidade (representação) da universidade. Entretanto, o professor demonstra resistência, resumindo-se a confessar o caso sem se encaixar aos padrões de confissão esperados e desejados pelo sistema institucional, pois acredita que não estava cometendo nenhum crime e que estão vivendo "tempos puritanos", quando a vida privada é assunto público. $O$ conselho de julgamento da universidade objetiva que o professor admita seu erro publicamente, com uma declaração que, segundo ele, independe da sua sinceridade, haja vista que considera sua sinceridade algo seu, com sua consciência e, para ele, não está fazendo nada intransigente, apenas seguindo seus desejos.

Um colega professor integrante do conselho julgador tenta alertá-lo da situação, afirmando tratar-se de uma relação sexual mediada pelo poder:

\footnotetext{
"Você não acha", diz Swarts, "que a natureza da vida acadêmica exige certos sacrifícios? Que para o bem de todos devemos nos furtar a certos prazeres?" "O que você tem em mente é a proibição de intimidade entre gerações?" "Não, não necessariamente. Mas como professores ocupamos posições de poder. Talvez proibir a mistura de poder com relações sexuais. Que eu sinto que era o que estava acontecendo neste caso." (COETZEE, 2011, p. 65, grifo nosso).
}

No entanto, D. Lurie entende que seu caso com a aluna tem por base os "direitos de desejo", "aquele deus que faz até os passarinhos estremecerem". Ao explicá-lo para sua filha, Lucy, (já na segunda parte do livro), faz uso comparativo da história de um cachorro que foi propriedade de antigos vizinhos. Segundo Lurie, por ser macho, sempre que aparecia uma cadela pela vizinhança, o cachorro ficava excitado, incontrolável, e seus donos batiam nele. Foi assim até que o cachorro não soubesse mais o que fazer. Ao avistar uma cadela, corria e gemia tentando se esconder, de forma que, se se submetesse à sua natureza, seria castigado. Nos dizeres de Lurie:

"Era uma coisa tão ignóbil que eu ficava desesperado. Acredito que se possa castigar um cachorro por uma coisa como roer um chinelo. O cachorro aceita a justiça de uma coisa dessas: uma surra por um chinelo roído. Mas desejo é outra história. Nenhum animal aceita uma justiça que castiga porque você obedeceu seus instintos." 
"Então os machos devem ter o direito de obedecer seus instintos livremente? É essa a moral da história?"

"Não, não é essa a moral. O que era ignóbil [...] é que o cachorro começou a odiar a própria natureza. Ele nem precisava mais apanhar. Ele mesmo já se castigava. Chegou a um ponto que era melhor matar logo o coitado."

"Ou corrigir."

"Talvez. Mas no fundo acredito que ele ia preferir ser morto. Ele talvez preferisse isso às opções que tinha: de um lado, negar a própria natureza; de outro, passar o resto da vida andando pela sala, suspirando, farejando o gato e engordando." (COETZEE, 2011, p. 108-109, grifo nosso).

Não vislumbrando seu erro, acredita estar dentro dos padrões "naturais" de comportamento. Diante da sua resistência, é demitido da instituição, fato que o faz viajar para passar alguns dias na casa de sua filha Lucy, lésbica e moradora de uma pequena fazenda no interior da África do Sul, em uma região afastada. Ocorre que, chegando lá, presencia a sua filha ser estuprada por três homens enquanto é mantido trancado em um lavabo da residência. Do deslinde do crime, sua filha, além de resistir a noticiar para as autoridades policiais, ainda resta grávida. Ou seja, toda a obra se desenvolve com acontecimentos relacionados à violência sexual. Primeiro Lurie é acusado, pela universidade, de assédio sexual à Melanie, e depois sua filha, Lucy, é vítima de estupro coletivo.

Coetzee tenta chocar o leitor com a normalidade com que em determinados casos a mulher vítima de estupro se sujeita a determinadas situações e, outras vezes, até mesmo aceita a violência sem denunciar (como foi o caso de Lucy). Do início ao fim a história se desenrola com frases que expressam relação de poder do homem sobre a mulher de forma que pareça "natural". A naturalização da violência causa a dificuldade de as mulheres a caracterizarem, pois muitas vezes a naturalidade com que é concebida social e culturalmente torna possível que muitas entendam por normal atitudes que representam ruptura de integridade (física, psicológica, emocional, moral...).

Quando Lurie abusa de Melanie, a jovem aluna, mesmo resistindo, acaba aceitando os abusos, silenciosa, e a única forma que encontra para que tudo cesse é deixando de frequentar as aulas, ou seja, prejudicando seu desenvolvimento intelectual a fim de cessar contato. Lucy, por sua vez, nem sequer comunica o crime às autoridades policiais. Quando da presença deles na residência local do crime, a moça só revela o roubo, representando a impunidade dos autores de violência sexual diante da inércia da vítima em denunciar a violência sexual.

Desonra traz uma história não só de abuso, mas de humilhação e sujeição: as personagens passam e consentem, aceitam como parte natural de sua trajetória o estupro. E o leitor fica incomodado com a falta de atitude das vítimas de abuso, no entanto, é a realidade refletida na literatura.

As vítimas não jogam a culpa nos abusadores, mas a assumem e entendem que devem convivê-la. Na obra, reflete-se nas manifestações de Lucy, que tenta compreender tudo pelo que passou e, ao final, aceita como parte de sua jornada. No livro é possível visualizar a crítica que o autor fez a essa impunidade quando D. Lurie pensa sozinho sobre o estupro de sua filha Lucy e a 
opção dela em não comunicar todo o ocorrido à autoridade policial, atendo-se somente a informar sobre o roubo, com o único intuito de receber o valor do seguro para os objetos subtraídos.

Vão ler que estão sendo procurados por assalto e roubo e nada mais. Vão entender que sobre o corpo da mulher o silencio se estenderá como um cobertor. Vergonha, dirão entre eles, vergonha de contar, e vão rir maliciosamente, relembrando a aventura. (COETZEE, 2011, p. 131, grifo nosso).

Referente à Lucy, o autor descreve sua atitude inerte diante da presença questionadora dos policiais:

\begin{abstract}
Ela não responde. Prefere esconder a cara, e ele sabe por quê. Porque está em desgraça. Porque sente vergonha. Foi isso que os visitantes conseguiram; foi isso que fizeram com essa jovem moderna, confiante. [...] Não é a história dela que se espalha, mas a deles: eles são os donos. Como eles a puseram em seu lugar, como the mostraram para que serve uma mulher. (COETZEE, 2011, p. 137, grifo nosso).
\end{abstract}

É importante observar que D. Lurie, quando no papel de agressor em relação à sua aluna, não se via como tal. Achava estar respeitando seus desejos naturais e reclamava da forma de intervenção social na vida privada (sexual) dele, além de não dar atenção ao pai da jovem Melanie quando este o procurou. Achava tudo aquilo um exagero. Era "só" um envolvimento entre gerações. No entanto, quando sua filha é estuprada, se vê profundamente incomodado. Pensa que é inadmissível que os estupradores fiquem impunes, um absurdo sua filha manter silêncio, e mais embasbacado ainda fica quando presencia um dos estupradores morando com o caseiro da fazenda, tendo ciência de que ele sabia do ocorrido e nada faz ou fez, mas tolera e acha que o erro está em Lucy ser uma mulher, solteira, morando sozinha, abnegando de proteção masculina. Ademais, nessa inversão de papéis, ou seja, quando ele se veste do papel de pai da vítima, permanece em constante irresignação por ninguém lhe "dar ouvidos", inobstante tenha feito o mesmo com o pai de Melanie, a aluna com quem se envolveu.

Não somente sob a dificuldade que Lucy encontra em se comunicar com seu pai, comunicar o estupro - embora os dois soubessem o que ocorrera - que a história se desenrola, mas sob a tentativa da vítima em si mesma tentar compreender o que havia passado, entender o sentimento do homem em relação a ela e permanecer sob a constante sensação de medo e da incerteza de novos abusos. Em determinado ponto, após inúmeras discussões entre os protagonistas, permeados por intensa instabilidade psicológica, após o atentado que sofreram e várias tentativas de um compreender a atitude do outro, D. Lurie desabafa:

\footnotetext{
"Vou pronunciar as palavras que até agora evitamos dizer. Você foi estuprada. Múltiplo estupro. Por três homens." 


\begin{abstract}
"Mas você tem razão, eu não significava nada para eles, nada. Dava para sentir isso."

Há uma pausa. "Acho que são estupradores antes de mais nada. Roubar coisas é um mero incidente. Um negócio paralelo. O que eles fazem é estuprar." [...] "Mas não tem outro jeito de encarar a coisa, David? E se... e se esse for o preço que é preciso pagar para continuar?" [...]

"Quando se trata de homem e sexo, David, nada mais me surpreende. Talvez, para os homens, odiar uma mulher faça o sexo ficar mais excitante. Você é homem, deve saber. Quando faz sexo com uma estranha, quando encurrala, prende, submete, coloca todo seu peso em cima dela, não é um pouco como assassinar? Enfiar uma faca; excitante depois, deixar o corpo coberto de sangue, não dá a sensação de assassinato, de conseguir se safar de um assassinato? [...] É sujeição. Submissão." (COETZEE, 2011, p. 185-186, grifo nosso).
\end{abstract}

Lucy foi vítima de violência sexual num país que expressa uma cultura predominantemente machista, onde o homem poderia ter várias mulheres desde que conseguisse sustentá-las, de que a mulher ao casar valeria pelo seu dote, ${ }^{12}$ de que o homem deve se sentir o provedor e que demonstra o incômodo social diante da presença de uma mulher independente e sozinha por opção (Lucy foi amedrontada para que saísse de onde morava ou que, de uma vez por todas, escolhesse alguém para se colocar sob sua guarda. O que acabou acontecendo. A jovem cede. Sabia que precisava recomeçar).

No caso do estupro coletivo de Lucy, a vítima foi tomada por uma grande vergonha após o ataque, pois sabia que na região onde vivia a culpa foi atribuída a sua pessoa, pois não poderia ser uma jovem mulher, independente, morando numa fazenda, sozinha, solteira. Após o abuso, permanecia na presença constante do medo, pois sabia que sua emancipação em relação a uma figura masculina, o ódio que sentiam da mulher, tida como um qualquer, sem dignidade, substituído a qualquer tempo, e a relação de poder, excitava os agressores.

É muito comum visualizar a falta de aliados à pessoa que sofreu abuso, tal como realmente é, uma vítima. A sociedade costuma preferir culpá-la pela ocorrência do estupro em vez de incorporar mudança de pensamento no âmbito social e familiar. Isso sem falar quando não legitima a prática quando de sua ocorrência em determinadas situações, como no casamento (o já citado poder socialmente conferido ao homem, conforme Saffioti (1990).

O fato de atribuir à mulher, na maioria dos casos, parcela da culpa pela violência sexual que sofreu é um fator que, aliado a outros, influencia na prática do estupro, pois quando os violentadores notam que a sua indiscutível culpa é sempre atenuada e relativizada em razão de julgamentos sobre a vida regressa da vítima, seu comportamento, a roupa que vestia, onde estava, etc., enxergam uma possibilidade de impunidade. A sociedade repudia e legitima o estupro ao mesmo tempo.

Pateman (1993) reconhece que há a presença, de modo geral, da crença de que nas relações sexuais as mulheres dizem "não" quando querem dizer "sim". Além do que, é possível percebê-la nos casos de estupro e no tratamento que recebem nas cortes, demonstrando a falta de capacidade em

\footnotetext{
12 Fato possível de ser notado quando o caseiro da fazenda, Petrus, já casado com duas mulheres, propõe à Lucy casar-se com ele em troca de proteção. Ela lhe daria suas terras, e ele, por sua vez, garantiria que não mais seria atacada. Isso porque, sabia ela que, cedo ou tarde, "eles" voltariam.
} 
lidar com o tema e compreender o que é uma relação sexual consensual. Na obra em apreço visualizase no caso de D. Lurie com sua aluna, Melanie. O professor reconhecia a falta de desejo da vítima ("estupro não, não exatamente, mas indesejado mesmo assim, profundamente indesejado"), mas negava veemente tratar-se de estupro. A jovem negava sua visita, negava querer ter relações, mas o professor, como a maioria dos agressores, externam a cultura de achar que a mulher está "fazendo charminho", dizendo "não" quando quer dizer "sim".

Aliment (2016), ao analisar a prática do estupro na história americana e o papel do agressor, da vítima e da corte, acredita que o consentimento das mulheres tem sido desacreditado, e isso é resultado de uma cultura que aceita o máximo de resistência, pois esse fator demonstra como o não consentimento se sobrepõe ao que é compreendido por consentimento e estupro. Ainda, a autora traz como exemplo um estudo publicado pela Violence \& Gender no qual os homens, ao serem questionados se já haviam coagido alguma mulher à força, admitiam comportamentos sexualmente coercitivos, no entanto negavam alguma vez terem estuprado uma mulher. Dessa forma, conclui que a aceitação cultural da maior resistência indica como o não consentimento obscurece o que compreendemos por consentimento e estupro.

Além disso, por conta da naturalização da violência no âmbito social, muitas vezes as próprias mulheres não percebem quando estão sendo vítimas de violência sexista. Toda a vez que são diminuídas, objetificadas e vistas como seres submissos ao poder dos homens, inferiores a eles e desmerecedores de consideração, encontram-se diante de práticas violentas à honra, à moralidade, à integridade, a depender da forma que se externar (FARIA, 2005).

Em decorrência disso, Teles (2012) acredita que a maior facilidade em reconhecer o cometimento é quando realizado por desconhecidos do que quando praticado pelo próprio marido da vítima, por exemplo. No entanto, o que se percebe, como consequência de uma análise prática, é que a maioria dos crimes de violência sexual são cometidos por agressores conhecidos ou próximos das vítimas.

Na obra de Coetzee foram abordados os dois casos: o crime cometido por um professor na condição de tutela da vítima e, portanto, próximo e conhecido dela e, de outro lado, o crime cometido por estranhos à vítima. Contrariando as expectativas, a vítima que denunciou a violência era a que possuía alguma relação com o agressor, e a que se manteve em silêncio foi a vítima que não tinha qualquer conhecimento da identidade dos agressores.

Visto isso, e fazendo uma leitura do livro Desonra com o Inquérito Penal n. 3.932, vislumbra-se, tanto num quanto noutro, a presença de condutas e dizeres de subjugação da mulher. Na narrativa literária é possível perceber que o personagem não vê semelhança em suas atitudes com a prática do estupro. Na narrativa do procedimento penal também se visualiza a resistência da defesa em assemelhar os comentários do deputado ao crime de incitação ao crime de estupro, entendendo que, com sua fala, não subjugou a mulher, não se referiu à generalidade, bem como não deu ensejo para novas práticas atentatórias à dignidade sexual e moral feminina. Ou seja, é sempre uma atitude 
de negação por parte do ofensor. O Ministro relator reconhece que "a característica principal do sistema processual penal é um profundo desinteresse pela vítima" e, por isso, considera que discursos que relativizem a gravidade do estupro dão azo a agravar a vitimização secundária (atribuição de culpa à própria vítima em defesa do criminoso).

A violência sexual é um processo de intimidação pelo qual as mulheres são mantidas em estado de medo. $O$ argumento da negação por parte dos agressores do potencial intimidatório que infligem sob as vítimas, bem como o argumento de que seus comentários não dissipam e nem reforçam as mais variadas formas de violência à mulher, são percebidos tanto na obra (ficção), quanto no inquérito penal (realidade). Entretanto, como o próprio Min. Luiz Fux pondera, "tolerar a reprodução do discurso [é] fragilizar a proteção das mulheres perante o ordenamento jurídico, ampliando sua vitimização."

A própria Procuradoria-Geral da República se manifestou entendendo que, pelo comentário do deputado em afirmar que o estupro só seria obstado pela falta de beleza da deputada, provocou um abalo na sensação de segurança, pois o que impede a prática de estupro deve ser a legislação penal e não a beleza de uma pessoa. ${ }^{13}$ Ao homem não cabe escolher se a mulher é "merecedora" do estupro. O uso da palavra "merece" atribui a ideia de prêmio, favor, e a nenhuma mulher o estupro é um presente. Mais ainda, desvela o tom machista quando alia o termo à beleza da vítima, pois transmite a noção de que o merecimento do estupro é sempre uma possibilidade às mulheres bonitas ou que façam o gênero do agressor. Um homem não pode estar em condição de menosprezar a dignidade de uma mulher e avaliar se é digna de receber esse tipo de sofrimento e opressão. A contrário sensu, as mulheres feias, ou que não façam o gênero do agressor, teriam sorte (ou azar?̨) de, com sua feiura, não merecerem o estupro?

Como já foi dito, no livro e no Inquérito há uma naturalidade com que a violência sexual em relação às mulheres é concebida. O relator reconhece isso e considera que, por conta da multiplicidade de membros que compõem uma sociedade, ou seja, da diferença em valores sociais, culturais, econômicos, educacionais, entre outros, essa disparidade pode, dependendo dos valores locais de cada sociedade, tolerar e até mesmo incentivar "a prática de atitudes machistas e defende[r] a 'naturalidade' de uma posição superior do homem, nas mais diversas atividades." Na obra de Coetzee, é possível vislumbrar que o país onde a história se passa é predominantemente machista, onde o homem deve ser o proprietário, o provedor, ter quantas mulheres puder sustentar, violentar quem quiser, e a sociedade simplesmente aceita e, muitas vezes, legitima. Legitimação capaz de causar graves efeitos, como rebaixar a dignidade sexual feminina e, efetivamente, encorajar a prática de qualquer forma de violência a essa espécie de ser humano já historicamente subjugada.

\footnotetext{
13 Nas palavras da procuradoria: "Ao afirmar o estupro como prática possível, só obstado para a Deputada Maria do Rosário, 'porque ela é muito feia', o Denunciado abalou a sensação coletiva de segurança e tranquilidade pela ordem jurídica a todas as mulheres, de que não serão vítimas de estupro porque tal prática é coibida pela legislação penal."
} 


\section{Reflexões "sobre a democracia"}

Esta seção se dedica à análise do livro Sobre a Democracia, de Dahl, tecendo ligações com o Inquérito Penal n. 3.932. A obra trata sobre democracia, traçando, primeiramente, o aspecto histórico e sua possível origem para, posteriormente, analisar o que é, por que ela, quais as instituições políticas necessárias à sua formação, suas condições e variantes. Entretanto, tendo em vista a amplitude do tema, neste trabalho será abordado apenas o que for pertinente ao objetivo de análise (concepção feminista, integração da mulher).

O autor escreve que "a desigualdade - e não a igualdade - é uma condição natural da humanidade." Entretanto, mesmo sabendo disso, questiona: porque há inúmeros séculos se aceita uma ideia de igualdade humana ${ }^{14}$ Ao responder, Dahl (2001) entende que, muitas vezes, quando se fala sobre igualdade, não se expressa um julgamento concreto, mas uma pretensão futura. Nesse sentido, quando se refere à igualdade está se "expressando um julgamento moral sobre seres humanos", tencionando-se ao que deveria ser, ou seja, considerar todos como intrinsecamente iguais. ${ }^{15}$

Rosseau (2010) já concebeu na espécie humana duas formas de desigualdade: a natural ou física, estabelecida pela natureza, relativa a diferenças de idade, físico, qualidades da alma; e a moral ou política, que é convencionada, que surge pelo consentimento, referente aos privilégios que alguns gozam perante os outros. Pode-se dizer que Dahl (2001) aderiu à igualdade estabelecida pela natureza para compor a ideia de que o julgamento moral expressa que não há superioridade na vida, liberdade, felicidade e outros bens fundamentais de uma pessoa em relação à outra. Isso se chama igualdade intrinseca.

No entanto, para aplicar o princípio da igualdade intrínseca ao governo de um Estado, no empenho de atingir a igualdade política, ou seja, para que as instituições consigam desenvolver os direitos de seus cidadãos e protejam seus valores e interesses fundamentais, o ideal é acrescentá-lo ao princípio suplementar, implícito naquele, qual seja: "ao chegar a decisões, o governo deve dar igual peso ao bem e aos interesses de todas as pessoas ligadas por tais decisões." (DAHL, 2001). A razão de adotar o princípio da igualdade intrínseca e aplicá-lo ao governo de um Estado, obrigando-o a dar igual peso aos interesses de todos e todas, justifica-se na ideia de que "a igualdade intrínseca abrange uma ideia tão fundamental sobre os méritos dos seres humanos, que está bem perto dos limites de maior justificação racional." (DAHL, 2001). A adoção desse princípio ocorre, em primeiro, porque está de acordo com a maioria das convicções e princípios éticos essenciais das pessoas em todo o mundo - de acordo com as bases éticas e religiosas; em segundo, pois a adoção de um princípio

\footnotetext{
14 Nesse sentido, traz-se à lembrança a Constituição Federal Brasileira, que em seu artigo $5^{\circ}$ dispõe: "Todos são iguais perante a lei, sem distinção de qualquer natureza, garantindo-se aos brasileiros e aos estrangeiros residentes no País a inviolabilidade do direito à vida, à liberdade, à igualdade, à segurança e à propriedade, nos termos seguintes: [...]"

15 Em sentido semelhante, Herrera Flores (2010), para quem os direitos humanos servem como uma narrativa, pois estabelecem processualmente as relações entre o mundo normativo e o material, entre as demandas ético-culturais da comunidade e a possibilidade real de implementação.
} 
alternativo à igualdade intrínseca pode ser mais frágil e duvidoso (p. ex., superioridade intrínseca); à prudência, por ser melhor garantir um governo em que os interesses recebam igual peso do que um governo no qual os interesses de um grupo prevaleçam sobre de outros; e, por fim, por questões de aceitabilidade, pois um processo que assegure igual peso aos interesses de todos tem maiores chances de ter consenso de todos e todas e, assim, atingir seus objetivos (DAHL, 2001).

Levando em conta essas reflexões sobre igualdade intrínseca, o autor conclui pela sua distinção em relação à superioridade intrínseca. Além disso, torna-se possível perceber, tanto pelo discurso contido no Inquérito Penal n. 3.932, quanto na obra Desonra, que os "protagonistas homens" se colocam num papel de superioridade intrínseca em relação às mulheres, ao invés de conceber todas com igualdade intrínseca. No Inquérito, o deputado se considera detentor do poder de julgar o merecimento de uma mulher, em razão da sua beleza ou sua "feiura", ao recebimento de uma violência sexual (prática atentatória da dignidade e causadora de graves consequências físicas, psicológicas e morais). No livro, o David Lurie considera suas atitudes em relação às mulheres como normais, entende que ele e todos os homens têm o direito ao corpo delas, pois "a beleza deve ser compartilhada" e que ela "não é dona de si mesma."

Além disso, como demonstração de superioridade intrínseca, tanto no inquérito quanto na obra de Coetzee, ou seja, tanto o deputado quanto o personagem não acreditam estar praticando ou dissipando violência sexual. $O$ deputado considera estar no seu direito de expressão e posteriormente argui como defesa que tem o direito de achar uma mulher feia ou não e que seus adjetivos não podem ser considerados ofensivos - apesar de terem sido utilizados como motivo que obstaria a prática do estupro, pois caso contrário fosse, o estupro poderia ocorrer e seria merecido. O personagem D. Lurie não encara suas invasões à vida das mulheres que se envolve como anormal, nem suas atitudes em relação a sua aluna, Melanie, como estupro.

Ainda, a partir desse raciocínio entre igualdade e superioridade, é possível extrair uma segunda diferença: entre integração e inclusão. Estar integrado é diferente de estar incluído. Os direitos humanos promovem a inclusão, daí sua importância para um país democrático. Dessa forma, para que a inclusão seja possível, num regime de governo democrático, a premissa que deve ser considerada é a da igualdade intrínseca. Não sem razão Sampere (2005) defende a tese de que o pluralismo democrático é a única garantia da igual dignidade humana de cada pessoa, igual dignidade que outras concepções fundadas em pressupostos distintos não reconhecem, nem respeitam, pois estabelecem uma hierarquia entre os dois sexos, nos últimos três mil anos do masculino sobre o feminino; entre as raças ou etnias entre umas ou outras religiões e a liberdade ideológica, entre as línguas, etc. Partem de vínculos pré-jurídicos que estabelecem a superioridade de umas pessoas sobre as outras para outorgar alguns privilégios ou todos os privilégios a algumas pessoas ou a uma só delas, habitualmente do sexo masculino, em detrimento das demais.

Nesse contexto, Sampere (2005) pontua que o núcleo de articulação político-jurídica do Estado democrático é o princípio da igualdade e não discriminação. A igualdade se opõe à 
desigualdade e é o contrário de identidade. Somos iguais em direitos individuais para poder expressar nossa diferente individualidade. Esse é o pressuposto e a condição para que cada pessoa possa ter uma vontade própria, que manifesta exercendo a seu modo, dentro do respeito das normas democráticas, pelo exercício dos direitos fundamentais que a Constituição reconhece e garante.

Para tanto, como exigências mínimas para se considerar um país como democrático, Dahl (2001) elege seis instituições políticas: funcionários eleitos; eleições livres, justas e frequentes; liberdade de expressão; fontes de informação diversificadas; autonomia para as associações; e cidadania inclusiva. No século XIX as primeiras cinco instituições políticas democráticas já estavam concretizadas na América do Norte. No século seguinte, já haviam se concretizado em muitos outros países, inclusive da Europa. Entretanto, ainda faltava a implementação da sexta instituição fundamental, a cidadania inclusiva, definida como a impossibilidade de negar a qualquer adulto com residência fixa no país, e sujeito a suas leis, os direitos necessários para as outras cinco instituições (DAHL, 2001).

Assim, embora alguns países dos Estados Unidos fossem concebidos como universalmente democráticos, essa universalidade não incluía as mulheres. Também ficavam de fora alguns homens e a maioria dos afro-americanos. Desse modo, embora proclamassem ser países democráticos, boa parte dos adultos era excluída da vida política simplesmente por sua condição (ser mulher), e negado o sufrágio universal a alguns homens por não satisfazerem algumas condições (porque não eram alfabetizados, porque não tinham propriedades, porque não eram brancos, etc.) (DAHL, 2001).

À vista disso, em muitos dos países considerados "altamente democráticos", como Bélgica, França e Suíça, as mulheres obtiveram o direito de voto somente após a Segunda Guerra Mundial (DAHL, 2001). Com isso, recorda-se que foram as duas grandes Guerras Mundiais as fortes responsáveis pela conquista de direitos pelas mulheres. Isso porque foi com a ida dos homens à Primeira Guerra Mundial na Europa que elas precisaram assumir os postos ocupados por eles nas fábricas e campos, enquanto eles guerrilhavam. Dessa forma, até mesmo suas vestimentas exageradas, longos vestidos, espartilhos e sapatos foram substituídos por trajes que lhes fizessem aptas ao labor (DEL PRIORE, 2011).

Com a ida dos homens à guerra, as mulheres tiveram a possibilidade de sair das funções exercidas exclusivamente no lar em favor da família para exercer temporariamente os postos até então masculinos, ocasião que tornou possível demonstrarem sua igual capacidade laboral em relação aos homens no desempenho das mesmas funções, possibilitando, como consequência, uma gradual conquista de direitos e inserindo-se cada vez mais na qualidade de cidadãs. Foi com as transformações políticas, econômicas e morais fruto do pós-guerra, a partir dos anos 1970, que o feminismo contemporâneo tomou vez e as mulheres passaram a exigir a igualdade (DEL PRIORE, 2011). Nessa perspectiva, foi após as duas grandes Guerras no século XX que surgiu o conceito de direitos humanos, dessa vez com a pretensão de estender-se a toda humanidade, e não somente como direitos do homem burguês, branco e capitalista (HERRERA FLORES, 2010). 
Como síntese, Dahl (2001) registra que por 25 séculos o que se compreendia por democracia e república, na verdade, restringia os direitos de participar ativamente na vida política a uma minoria de adultos, sendo que, somente a partir do século XX pôde-se falar em uma democracia que exigisse a extensão do direito de se envolver plenamente na vida política a todos os adultos que residissem permanentemente em determinado país. Dessa forma, as seis instituições políticas são consideradas uma nova forma de democracia, um novo tipo de regime político que, em conjunto, jamais existiu. São instituições de um modelo representativo democrático moderno, por isso inédito. Esse governo democrático chama-se poliarquia, democracia poliárquica (DAHL, 2001).

A poliarquia seria, basicamente, um governo democrático moderno constituído pelo conjunto das seis instituições políticas citadas previamente. Ela difere das outras formas de democracia, pois não é como a democracia representativa do século XIX, na qual o sufrágio era restrito. Também difere das práticas democráticas dos pequenos grupos, em que os membros podem participar e decidir diretamente (DAHL, 2001). A poliarquia é o governo de todos. Desse modo, a democracia poliárquica (com suas seis instituições políticas) surgiu como forma de "reação a exigências de inclusão e participação na vida política." Os países hoje considerados democráticos são formados por uma democracia que tem presente todas essas seis instituições - e não somente parte delas (DAHL, 2001).

Fazendo uma ligação da obra no que se refere à inclusão com o Inquérito penal n. 3.932, em determinado trecho o relator expõe que:

O direito exerce importante papel na construção social das diversas e variadas subjetividades, donde decorre a necessidade de os operadores jurídicos considerarem a realidade das relações sociais, com o fim de consolidar um olhar distinto diante da discriminação e da violência que caracterizam as relações de gênero no país. (grifo nosso).

A sociedade não é formada só de um grupo de pessoas que possuem identidade entre si. Diante da variedade ${ }^{16}$ de grupos, classes sociais, raças e credos, o direito, sempre avançando, tem como papel o dever de se manter em constante inovação para acompanhar a necessidade de todos e todas que compõem o seio social, de forma a objetivar sempre o máximo de inclusão. Todavia, o direito não é o único responsável por formar convicções, nem o único capaz de provocar mudanças em situações desrespeitosas, de violência, desonra e desprezo à dignidade.

Não se trata de desconsiderar os apelos à justiça e aos direitos humanos para se posicionar contra situações desonrosas. No entanto, muitas vezes, admitir que certas situações são erradas, ilegais, imorais e irreligiosas não é o suficiente para incentivar a mudança; é necessário que a honra seja considerada uma desonra. Ou seja, remodelar o construto social da honra. Esse é o principal argumento de Appiah (2012).

$\overline{16}$ Já dispunha Said (1993) que todas as culturas estão conectadas, não são pura e única, ao contrário, sofrem influência uma da outra, sendo, ao mesmo tempo, heterogêneas, diferentes entre si. 
Um exemplo do que Appiah (2012) entende por códigos de honra pode ser vislumbrado nas palavras do relator no inquérito penal em análise neste trabalho:

[O índice de violência à mulher no Brasil é alto.] Contribui para esse quadro o fato de que a legislação, até não muito tempo atrás, estabelecia "os costumes" como bem jurídico protegido dessa criminalização e, ainda mais grave, que considerava apenas a "mulher honesta" como possível vítima - quiçá, até 1940, se entendesse que as demais mulheres "mereciam" a violência.

Todo esse contexto retira das mulheres espaços importantes de exercício de suas liberdades públicas, seja nas grandes urbes ou no grande interior do país; no âmbito familiar ou no meio social, acadêmico, profissional. (grifo nosso).

O Ministro confirma que não só o direito contribui para os acontecimentos do quadro social, mas também os costumes. Dessa forma, não só o direito e a legislação são responsáveis por criar situações, impedi-las ou mudá-las, mas o costume e, para Appiah, a honra.

Appiah (2012, p. 175) acredita que, diante do vislumbre de uma injustiça, ou seja, de práticas desonrosas em determinado lugar do mundo, o único método capaz de mudar a honra (por trás de determinada prática, ou seja, a honra que os violadores acreditam estar presente no cometimento do crime, que o assegura) é por meio da própria honra. Segundo o autor, "em todas as revoluções anteriores, o poder motivador da honra manteve-se inconteste. Pelo visto, a maneira correta de avançar não é argumentar contra a honra, mas trabalhar para mudar os fundamentos dela." (APPIAH, 2012, p. 175).

O método para mudar os fundamentos da honra, o qual se denomina "filiação simbólica", consiste em fazer com que pessoas pertencentes a determinado grupo, não propriamente envolvido, enxerguem que determinada prática, em outro local, também desonra (APPIAH, 2012). Explica-se: para desestabilizar os códigos de honra, atrai-se a atenção de pessoas a uma determinada luta contra uma prática que pressupõe também desonrá-las. É o caso das práticas denegatórias de direitos ou atentatórias às mulheres. Mulheres de outro canto do mundo sentem-se, juntamente às vítimas diretas, também desonradas e despertam para pressionar, por meio de organizações feministas e de direitos humanos que formam, os códigos de honra que idealizam a indivisibilidade feminina.

É a revisão das práticas de honra. No caso das mulheres, mostrar aos homens que o novo elemento da honra masculina é o respeito pelas mulheres. A honra "combatendo" a honra (APPIAH, 2012).

Cabe reformar a honra referente a todas as formas de violência e discriminação sexual e, em particular, toda sociedade precisa manter códigos em que o ataque a uma mulher - $\mathrm{o}$ ataque a qualquer pessoa - de sua família seja fonte de desonra e motivo de vergonha. (APPIAH, 2012, p. 175-176, grifo nosso).

Mill (2006) já discorreu que o princípio do movimento moderno, tanto na moral quanto na política, dispõe que só a conduta é capaz de conferir direito ao respeito, pois não é o que os homens são, mas o que fazem, que os autoriza a ter respeito e consideração dos outros, e que não é o nascimento, mas o mérito, que os permite reivindicar legitimamente por poder e autoridade. No 
inquérito penal, entendeu-se que a campanha virtual "\#eunãomereçoserestuprada", que surgiu em consequência às declarações do parlamentar, teve como intuito expor o que é considerado ofensa grave às mulheres. Isso é o que Appiah (2012) acredita: por meio da indignação do grupo "alheio" ao que foi diretamente ofendido, expor para toda a classe que determinada prática fere a dignidade e a honra de todos e todas. É assim que se atinge a mudança: demonstrar que uma prática criminosa que é considerada honrosa (no caso, para os homens - poder, superioridade e submissão), na verdade não tem mais nada a ver com o que se considera honra no século XXI (respeito ao próximo como semelhante e portador de igual dignidade). Essa é a "filiação simbólica" da honra: utilizar a contranarrativa para combater os fundamentos de um construto social machista.

Assim, reforça-se o que o Appiah (2012) acredita. As medidas legais de combate às discriminações, bem como as legislações protetoras feministas visam eliminar as injustiças de uma sociedade e contribuir com a situação das minorias, contudo não são capazes, por si só, de promover de fato uma revolução moral dos códigos de honra em países permeados de muita influência cultural, respingando diretamente no modo de agir das pessoas.

Essa também é a opinião de Herrera Flores (2010, p. 96). Pode-se perceber, pela análise das normas e suas respectivas teorias, a dificuldade jurídica e institucional para contemplar as necessidades, valores e expectativas das grandes camadas da população. Isso porque, "o patriarcalismo, o individualismo possessivo e o formalismo estão nas bases da dita norma fundamental, [...] da dita cultura jurídica dominante." Considerando isso, por mais que, muitas vezes, as legislações promovam determinadas garantias, a carga cultura $1{ }^{17}$ é muito mais forte e a interpretação que se dá quando da transgressão do que está determinado legalmente acaba sendo mediada, a ponto de tornar nefasto tudo o que é determinado como legalmente coerente.

É o caso da Índia, ${ }^{18}$ onde o estupro marital não é considerado crime, porque, em decorrência da religião, o casamento é considerado sagrado, e os casos de violência sexual dentro dos relacionamentos conjugais restam impunes ante à submissão que as mulheres devem ter em relação ao marido no casamento, ao passo que este é considerado uma fonte de prazer sexual ao homem. Isto é, apesar de a Constituição Indiana assegurar igualdade de direitos entre homens e mulheres, ${ }^{19}$ a religião dispõe de forma diferente e, por ser um país com um sistema legal muito influenciado religiosamente, às mulheres resta um tratamento inferior ao dos homens, conforme ditado pela religião que seguem (NUSSBAUM, 2000). E, não muito longe, é o caso visualizado no livro Desonra,

\footnotetext{
17 Nesse sentido, também, manifestação do relator no voto do Inquérito Penal n. 3.932: "O desprezo demonstrado pelo bem jurídico protegido (dignidade sexual) reforça e incentiva a perpetuação dos traços de uma cultura que ainda subjuga a mulher, com potencial de instigar variados grupos a lançarem sobre a própria vítima a culpa por ser alvo de criminosos sexuais, deixando, a depender da situação, de reprovar a violação sexual, como seria exigivel mercê da expectativa normativa.

18 Para mais informações: POR QUE... (2015).

19 Right to Equality: 14. The State shall not deny to any person equality before the law or the equal protection of the laws within the territory of India;

15. (1) The State shall not discriminate against any citizen on grounds only of religion, race, caste, sex, place of birth or any of them. (2) No citizen shall, on grounds only of religion, race, caste, sex, place of birth or any of them, be subject to any disability, liability, restriction or condition with regard to [...] (INDIA, 2007).
} 
em que Lucy, quando violentada, sabe ser irrelevante denunciar o estupro coletivo que sofreu, pois naquele local onde escolheu para morar, era assim que as coisas funcionavam.

Diante disso, vislumbra-se a necessidade de entender a origem das desonras e tentar, de forma conjunta, unificando o direito, a moral, os costumes e a honra, garantir, num grau máximo possível, a igualdade intrínseca dos seres humanos considerados em si mesmos, dentro de um regime democrático que respeita e reconhece os direitos fundamentais. Com acerto, Sampere (2005), ao responder a pergunta de Michael Carrithers "Por que os humanos temos culturas?, assume que a diversidade das formas de vida humana descansa sobre o fundo comum da sociabilidade das pessoas. A capacidade de interação social, entre indivíduos ou em grande escala, é o impulso ao contínuo processo de inovação da humanidade. A inteligência humana, que é uma inteligência social, inventa possibilidades, imagina, concebe, modifica, e criou uma imensa e complexa rede de diferentes sociedades, culturas e histórias. Com efeito, se a vida humana é metamórfica e as culturas e códigos de honra pressupõem relações, essas intersubjetividades podem ser alteradas, superadas e desenvolvidas sobre outras premissas inclusivas e não discriminatórias para remodelar o construto social da honra. Se um código de honra machista foi humanamente criado, esse mesmo código (desonroso) pode ser humanamente modificado, e superado.

\section{Considerações finais}

No decorrer do trabalho, analisou-se sobre a concepção da mulher e o tratamento que lhes é dispensado por meio de atitudes e comentários refletidos no Inquérito Penal n. 3.932, envolvendo os parlamentares Jair Messias Bolsonaro e Maria do Rosário, em trâmite no Supremo Tribunal Federal, e entre as obras Desonra, de J. M. Coetzee, e Sobre a Democracia, de Robert Dahl. Na primeira parte, foram analisados os comentários proferidos em eventos distintos pelo parlamentar Jair Messias Bolsonaro em face à também parlamentar Maria do Rosário, avaliando as razões jurídicas relativas aos crimes atribuídos em consequência do discurso do denunciado. Atribuiu-se ao parlamentar o crime de incitação ao crime, por considerar que, com as palavras dirigidas à parlamentar, estaria incitando a praticar o crime de estupro. Essa conclusão foi alcançada por considerar que, sobretudo com o uso da palavra "merecer", quando o denunciado disse que não estupraria a deputada por sua ausência de beleza ("muito feia") e porque "ela não merece", estaria insinuando que a violência sexual é um prêmio, uma benesse, e incitando outras pessoas a considerar ter o direito de escolher quais mulheres seriam beneficiadas com tal ato violador de dignidade (fato que inclusive deu azo a outras práticas desonrosas perpetradas por internautas em desfavor da parlamentar nas redes sociais). No tocante a esse crime, a denúncia foi recebida.

Atribuíram-se ao parlamentar também outros dois crimes: injúria e calúnia. Ao primeiro foi recebida a queixa-crime e, a respeito do segundo, foi rejeitada. A imputação do crime de injúria ocorreu pelas mesmas declarações proferidas pelo deputado, as quais teriam ofendido a honra 
subjetiva da vítima, além de associar as características da mulher à possibilidade de ser vítima estupro. O STF entendeu pelo processamento do crime atentatório à honra, pois vislumbrou presente o efetivo potencial de rebaixamento da dignidade moral ao ofender sua condição de mulher, presente, portanto, o animus offendendi. No tocante ao crime de calúnia, a queixa restou rejeitada, pois se atribui o crime ao querelado por ter afirmado falsamente que a querelante o chamou de "estuprador"; no entanto, o crime prevê a atribuição falsa de fato definido como crime, e a inicial não narra como a afirmação de o deputado ter sido chamado de "estuprador" pela querelante poderia ofendê-la em sua honra.

Na segunda parte, foi realizado o estudo do discurso atribuído às mulheres aliado à obra de Coetzee, cujo objetivo foi, comparando as narrativas de um caso real de um parlamentar brasileiro ao de uma criação literária, apresentar como se assemelham e fazer uma crítica ao lugar (representativo) imposto às mulheres, ou seja, de seres inferiores e submissos às vontades masculinas. Tal fato se visualiza tanto no inquérito quanto na obra, quando, naquele, o denunciado acredita dispor do poder de escolha em violentar uma mulher, do seu merecimento de abuso sexual, enquanto que, na obra, demonstraram-se dois casos de abuso sexual. A conexão entre eles é que tanto no inquérito quanto na obra literária, o denunciado (discurso) e o protagonista (prática) não acreditam ter violado a dignidade sexual das vítimas, caracterizando uma atitude de negação por parte do ofensor. Ademais, em ambos, verifica-se a naturalização da violência contra a dignidade sexual da mulher.

Na terceira parte deste trabalho realizou-se o estudo do livro Sobre a Democracia, de Robert Dahl, tecendo ligações com o Inquérito Penal n. 3.932. A obra de Dahl trata sobre democracia, na qual o autor explica que a condição natural da humanidade é a desigualdade, e não a igualdade, muito embora todos desejem esta, mas a ideia de igualdade humana é aceita por explicitar uma pretensão futura, demonstrando que almejar igualdade é tencionar para o que deveria ser (considerar todos iguais). É almejando a igualdade que se atinge a democracia, por isso foram apresentados os conceitos de igualdade intrínseca e superioridade intrínseca a fim de demonstrar os parâmetros para uma real e concreta democracia entre homens e mulheres, pois igualdade intrínseca significa considerar não haver superioridade na vida, liberdade, felicidade e outros bens fundamentais de uma pessoa em relação à outra.

Além disso, foram apresentados os conceitos do autor sobre poliarquia (democracia poliárquica), considerado um sistema político que jamais existiu, pois é constituído das seis instituições políticas que, em conjunto, formam o que é, de fato, considerado um regime democrático. Adota-se o procedente argumento de "filiação simbólica" de Antony Kwame Appiah, que consiste em fazer com que pessoas pertencentes a determinado grupo, não propriamente envolvido, enxerguem que determinada prática, em outro local, também desonra. De fato, diante do vislumbre de uma injustiça, ou seja, de práticas desonrosas em determinado lugar do mundo, o único método capaz de mudar a honra (por trás de determinada prática, ou seja, a honra que os violadores acreditam estar presente no cometimento do crime, que o assegura) é por meio da própria honra. $\bigcirc$ intuito é 
remodelar o construto social da honra. Se um código de honra machista foi humanamente criado, esse mesmo código (desonroso) pode ser humanamente modificado, e superado. Acredita-se que com a democracia poliárquica e com a filiação simbólica não retrocederemos a antigas formas políticas pré-modernas e pré-democráticas que, pela profunda desigualdade entre seus membros, já foram superadas pela História.

\section{Referências}

ALIMENT, Ruby. Saying "Yes": How California's Affirmative Consent Policy Can Transform Rape Culture. HeinOnline, v. 14, i. 1, Summer 2015. Disponível em: <http://heinonline.org/HOL/ Page? handle $=$ hein.journals/sjsj14\&div $=8 \&$ start_page $=187 \&$ collection $=$ journals \&set_as_cursor $=0 \&$ men_tab $=$ srchresults $>$. Acesso em: 06 jun. 2018.

APPIAH, Anthony Kwame. O código de honra: como ocorrem as revoluções morais. Tradução Denise Bottmann. 1. ed. São Paulo: Companhia das Letras, 2012.

CIFUENTES, Santos. Derechos personalísimos. Buenos Aires: Astrea, 1995.

COETZEE, John Maxwell. Desonra. São Paulo: Companhia das Letras, 2011.

CORDEIRO MENEZES, António. Tratado de Direito Civil Português, I Parte Geral, Tomo III, Pessoas. Coimbra: Almedina, 2004.

CUNHA E CRUZ, Marco Aurélio Rodrigues da. La configuración constitucional del derecho a la propia imagen en la Constitución brasileña de 1988. Sevilla: Universidad de Sevilla, 2009.

DAHL, Robert A. Sobre a Democracia. Tradução Beatriz Sidou. São Paulo: Editora Universidade de Brasília, 2011.

DEL PRIORE, Mary. Histórias intimas: sexualidade e erotismo na história do Brasil. São Paulo: Planeta do Brasil, 2011.

FARIA, Nalu. Para a erradicação da violência doméstica e sexual. In: NOBRE, Miriam; FARIA, Nalu; SILVEIRA, Maria Lúcia. Feminismo e Luta das Mulheres: análise e debates. SOF: São Paulo, 2005. Disponível em: <http://sof2.tempsite.ws/wp-content/uploads/2015/07/Livro_FemLutMulh.pdf >. Acesso em: 28 jun. 2017.

HERRERA FLORES, Joaquín. Los derechos humanos en el contexto de la globalización: três precisiones conceptuales. In: RUBIO, David Sanchez; HERRERA FLORES, Joaquín; CARVALHO, Salo de. Direitos humanos e globalização: fundamentos e possibilidades desde a teoria crítica. 2. ed. Porto Alegre: EDIPUCRS, 2010. Disponível em: <http://www.pucrs.br/edipucrs/direitoshumanos.pdf>. Acesso em: 11 jun. 2018.

INDIA. Ministry of Law and Justice. The Constitution of India. Dec. 2007. Disponível em: <http:// www.conteudojuridico.com.br/vade-mecum-estrangeiro,constituicao-da-india-constitution-of-india,31254.html>. Acesso em: 26 out. 2017.

KOHLER, Joseph. A Propria imagem no direito. Justitia, v. 34, n. 79, p. 23-43, out./dez. 1972. 
MILL, John Stuart. A sujeição das mulheres. Tradução Benedita Bettencourt. Edições Medina: Coimbra, 2006.

NUSSBAUM, Martha C. Woman and human development: the capabilities approach. Cambridge University Press, 2000.

PATEMAN, Carole. O contrato sexual. Tradução Marta Avancini. Rio de Janeiro: Paz e Terra, 1993.

POR QUE não é crime estuprar a esposa na Índia. News Brasil, 29 maio 2015. Disponível em: <http://www.bbc.com/portuguese/noticias/2015/05/150526_marital_rape_india_mv>. Acesso em: 26 out. 2017.

ROSSEAU, Jean-Jacques. Discurso sobre a origem da desigualdade entre os homens. Tradução Roberto Leal Ferreira. São Paulo. Martin Claret, 2010.

SAFFIOTI, Heleieth I. B. O poder do macho. 3. ed. São Paulo: Moderna, 1990.

SAID, Edward W. Cultura e imperialismo. Tradução Denise Bottmann. São Paulo: Companhia de bolso, 1993.

SAMPERE, Eva Marínez. El pluralismo democrático como garante de la dignidad humana: no al triunfo póstumo de Hitler. In: RUIZ, Gerardo Ruiz-Rico; PÉREZ-SOLA, Nicolás (Coord.). Constitución y cultura: retos del Derecho Constitucional en el siglo XXI. Valencia: Tirant lo Blanc, 2005. p. 244-269.

SUPERIOR TRIBUNAL DE JUSTIÇA. Recurso Especial No 1.642.310. Terceira Turma do Superior Tribunal de Justiça. Recorrente: Jair Messias Bolsonaro. Recorrida: Maria do Rosário Nunes. Relatora: Min. Nancy Andrighi. Julgamento em 15 ago. 2017. Diário de Justiça eletrônico, 18 ago. 2017. Diponível em: <https://ww2.stj.jus.br/websecstj/cgi/revista/REJ.cgi/ITA? seq=1624738\&tipo $=0 \&$ nreg $=201602640005 \&$ SeqCgrmaSessao $=\&$ CodOrgao $\mathrm{gdr}=\& d \mathrm{t}=20170818 \&$ formato $=$ PD F\&salvar $=$ false $>$. Acesso em: 12 jul. 2018.

SUPREMO TRIBUNAL FEDERAL. Inq 3932. Primeira Turma do Supremo Tribunal Federal. Autor: Ministério Público Federal. Investigado: Jair Messias Bolsonaro. Relator: Min. Luiz Fux. Julgmento em 21 de jun. 2016. Diário de Justiça eletrônico, 09 set. 2016. Disponível em: <http://redir.stf.jus.br/ paginadorpub/paginador.jsp?docTP=TP\&docID=11627210>. Acesso em: 12 jul. 2018.

TELES, Maria Amélia de Almeida; MELO; Mônica de Almeida. O que é violência contra a mulher. São Paulo: Brasiliense, 2012.

Data da submissão: 13 de julho de 2018 Aceito em: 13 de julho de 2018 